\title{
PARADIGM OF HISTORICAL SCIENCE IN DEVELOPMENT OF LAND TRANSPORTATION FACILITIES IN DKI JAKARTA
}

\author{
Alfi Miftachul Firdaus ${ }^{1}$, Moses Glorino Rumambo Pandin ${ }^{2}$ \\ Faculty of Humanities, Airlangga University \\ alfi.miftachul.firdaus-2020@fib.unair.ac.id,moses.glorino@fib.unair.ac.id
}

\begin{abstract}
Jakarta is the capital city of Indonesia, which has its own problems in building transportation facilities, especially on land routes. For private vehicle users, congestion is a common thing, given the very dense number of people living in Jakarta, both natives and migrants from outside the region. And for users of public transportation services such as city transportation (angkot) and transjakarta, convenience is the main obstacle. And even though it is a public vehicle, it cannot avoid congestion because it is in one lane with private vehicles except for the transjakarta bus which has its own lane. Meanwhile, for train-based public transportation such as MRT (Mass Rapid Transit), LRT (Light rail Transit), and electric railroad (KRL), the problem is the lack of integration, namely that many stations are not yet integrated with other transportation. Various policies have been implemented to overcome these problems. This study aims to determine the level of effectiveness and efficiency of public transportation in DKI Jakarta today. The method used in this research is qualitative-descriptive through a literature review on 16 journal articles and 4 websites. The results of this study indicate that congestion is a major problem in the means of transportation in Jakarta. This is due to the increase in population due to urbanization which is also accompanied by an increase in the number of private vehicles. Therefore, to overcome this, the Jakarta Provincial Government has made improvements, reforms, and developments in public transportation. And it is hoped that people who originally used private vehicles will switch to using public transportation. But in reality, various problems in public transportation in Jakarta have not been resolved properly. Especially why traffic jams still occur?, and what are the solutions to overcome them?. It is hoped that the results of the findings of this study can be used as a reference in making or designing policies and can contribute to overcoming problems in the transportation sector, especially in the DKI Jakarta area. The limit of this research is that it only focuses on land transportation facilities in Jakarta.
\end{abstract}

Keywords: effectiveness, efficiency, Jakarta, transportation

\section{INTRODUCTION}

The history of land public transportation in Jakarta has been started since the colonial era (1). At that time Indonesia was controlled by the Dutch and Jakarta was still called Batavia. In 1869 there was already a horse tram that could accommodate 40 people pulled by $3-4$ horses (2). At the beginning of its appearance, the tram train was used as a means of transporting various commodities to be taken to the port which would then be transported by ship. Then in 1883 the horse tram was changed to a steam tram due to operational constraints on the part of the management and was taken over by another company which eventually carried out an 
overhaul, from a horse-powered tram to a steam-powered tram. After four years of operation of the steam tram, under the operation of the Batavia Elekrische Tram Maatschappij the electric tram was present and continued to develop, until 1935 other land transportation modes appeared, namely bemo and oplet which became a sign of the beginning of the decline of the tram.

Oplet is a public transportation vehicle that comes from cars made in England. This public transportation existed in the 1970s and is the most popular public transportation in Jakarta. And to facilitate the operation of public transportation such as oplets, the government built a terminal in the Jatinegara area in 1968. The oplet operation route starts from the Jatinegara terminal through Mataram Raya, Salemba Raya, Pasar Baru and rotates at Harmoni. However, in 1979 the oplet operation as public transportation was stopped and replaced with a more modern public transportation, namely the Microbus. After that, public transportation based on cars or buses in Jakarta continues to change along with the times.

However, the times that are increasingly advanced have not been able to solve the transportation problems that exist in Jakarta. The problem is how to meet the demand for the number of trips that are increasing but not causing congestion (3). Population growth and increased community mobility are one of the factors that cause these problems (4). Thus public transportation is the solution, if the majority use public transportation, congestion will not occur because the number of vehicles on the roads will decrease.

However in reality, public transportation still has various deficiencies both in terms of services and facilities, so that the majority of people are reluctant to use public transportation and prefer to use private vehicles because they are considered more comfortable, safe, and flexible in their use. Based on these factors private vehicles are clearly more efficient than public transportation. But the uncontrolled increase in the number of private vehicles can cause various problems such as increased fuel use, air pollution, and traffic congestion (5).

These problems deserve to be investigated more deeply because public transportation plays an important role in economic development in a city. In addition, public transportation is also the backbone of the urban economy which can be an indicator that a city has a good urban planning system. This is because transportation cannot be separated from the high mobility of society in the distribution of materials and the movement of human and goods activities as a micro component of an economy. Transportation facilities must be able to provide convenience for the entire community in carrying out all activities in all different locations and spread with different physical characteristics. 
Given the main cause of congestion is the number of private vehicles that continue to increase. So the solution that can be applied is to switch to using public transportation. This can be realized if public transportation can work more effectively and efficiently than private vehicles. The use of public transportation also helps to minimize the use of fuel and air pollution.

Various policy steps and infrastructure development have been taken to overcome these problems. Such as the application of odd-even policies on motorized vehicles based on plate numbers and the development of new types of public transportation modes. Until now, there are five types of public transportation in Jakarta, namely city transportation (angkot), transjakarta buses, MRT (Mass Rapid Transit), LRT (Light rail Transit), and electric rail trains (KRL). However, with the available public transportation, why do traffic jams still occur? and what are the solutions to overcome them?

\section{METHOD}

The method used in this study is a qualitative approach, namely a research method based on the philosophy of postpositivism. This method is used for research with natural objects, not experiments. And the researcher acts as a key instrument. The results of research using qualitative methods emphasize more on meaning than generalization (21).

Data used in this study came from 3 types of sources, namely electronic books, journal articles, and websites. Data used are 23 consisting of 3 electronic book, 16 journal articles, and 4 websites. And details of the journal articles used are 7 journal articles in 2020, 3 journal articles in 2019, and 6 journal articles from years before 2019.

The data used is data that is relevant to the topic of discussion in this study. The data was obtained by means of a literature review, namely a basic review used by the author to conduct further research following the topic of in-depth discussion (22). This technique is used by researchers in conducting a preliminary study that aims to find the main problem to be studied.

While the analysis technique used is descriptive analysis, namely statistics used to analyze data by describing the data that has been collected as is without intending to make conclusions that apply to the public or generalizations. At this stage the researchers conducted sorting and processing of the data that had been obtained. Furthermore, the data is presented in 
the form of text and tables. Then the data is analyzed so that conclusions can be drawn (23). The details of the analysis process carried out by researchers are as follows:

1. Researchers do sorting and processing data in accordance with the discussion.

2. Researchers present data in text form and also a summary table of results contained in the appendix.

3. Draw conclusions based on the data obtained by analyzing the data.

\section{RESULTS}

Currently, Indonesia is a country that is in the development stage. And one indication that a country is developing is a high flow of urbanization (6), that is, the migration of people from rural areas to urban areas based on the objective that one of them is to obtain a prosperous life. Because in big cities there is industrialization, this will increase the number of jobs which ultimately attracts rural people to urbanize to cities to get these jobs.

The result of urbanization will affect the population in a city. It is predicted that in 2025 about $60 \%$ of the people will live in urban areas. And if Indonesia's population in 2025 is 240 million people, then around 144 million people will live in urban areas. In the city of Jakarta itself, which is the capital city of Indonesia and has become a metropolitan city, the rate of urbanization is very high and the population has increased dramatically. In 2019 the population in DKI Jakarta reached 10,817,856 people with an area of $662.33 \mathrm{~km} 2$. Based on total population and area, the population density in DKI Jakarta is 16,704 people / km2 (7).

The increasing number of population also affects other aspects, one of which is the means of transportation. In Jakarta, both natives and immigrants, they cannot be separated from the means of transportation, either public transportation or private vehicles, because transportation has an important role in economic development related to the distribution of goods, services and labor. Jakarta as a metropolitan city has high traffic flow and mobility, especially in the morning when the activity starts and in the afternoon when the activity ends. This causes the number of vehicles on the road, both private and public vehicles, and traffic jams occur. 
Table 1. Population in Major City in Indonesia

\begin{tabular}{|l|l|r|r|}
\hline$\#$ & Kota & Provinsi & Jumlah Penduduk \\
\hline 1 & Jakarta & DKI Jakarta & 10.817 .856 \\
\hline 2 & Surabaya & Jawa Timur & 2.923 .681 \\
\hline 3 & Medan & Sumatera Utara & 2.502 .092 \\
\hline 4 & Bandung & Jawa Barat & 2.452 .179 \\
\hline 5 & Bekasi & Jawa Barat & 2.436 .577 \\
\hline 6 & Depok & Jawa Barat & 1.844 .932 \\
\hline 7 & Semarang & Jawa Tengah & 1.668 .578 \\
\hline 8 & Makassar & Sulawesi Selatan & 1.659 .777 \\
\hline 9 & Tangerang & Banten & 1.742 .604 \\
\hline 10 & Palembang & Sumatera Selatan & 1.592 .248 \\
\hline
\end{tabular}

Apart from being high in population, congestion is also supported by other factors such as the increasing number of private vehicles, people who prefer to use private vehicles and public transportation that cannot compete with private vehicles. People are reluctant to use public transportation because private vehicles are more comfortable, safer, and more flexible in use. Public transportation in Jakarta is also not well integrated.

To overcome traffic congestion, the DKI Jakarta Provincial Government has also made various efforts such as increasing road capacity or building new roads, engineering or traffic management, adding public transport fleets, and building new types of public transportation modes. Currently available public transportation in Jakarta are:

1. City Transport (Angkot)

Angkot has been operating since 1943 when Indonesia was still colonized by Japan. And in 1946, public transportation became part of DAMRI (Djawatan Angkoetan Motor Repoeblik Indonesia) as public transportation. Angkot is one of the transportation chosen by the community to mobilize before and after using the train, the reason people use city transportation more for mode shifting is because of easy access and there is no option to use other transportation (8). Angkots have become very popular because they are able to travel in relatively small vehicles that can contain 10 passengers in them. This public transportation is still operating today, especially for the middle to lower class. However, angkot cannot adjust to the pace of development of the times so that its existence is starting to be replaced by other public transportation. In addition, there are several things that make public transportation less attractive to the community, such as the determination of uncertain public transport rates, limited numbers, the feasibility of public transport 
vehicles related to comfort, and passenger safety from crimes such as pickpockets or others (9).

\section{Transjakarta}

Transjakarta is a public transportation owned by DKI Jakarta Regional Owned Enterprises (BUMD). Started operating in 2004 until today with a fleet of more than 2,000 buses and 200 travel routes. One of the advantages of the Transjakarta bus is that it has a special lane called the busway alias it is separated from the public road. The details of the reasons why people use Transjakarta are $39 \%$ answered that it is cheaper, $29 \%$ answered that it is easy to access, $14 \%$ is more comfortable, $7 \%$ is faster and safer and $2 \%$ has a higher level of safety than other transportation. And for details in the operation of the Transjakarta bus, the return trip frequency is $89 \%$, the maximum travel time is one to two hours by $57 \%$ and the waiting time at the bus stop is $\pm 10-15$ minutes by $42 \%$.

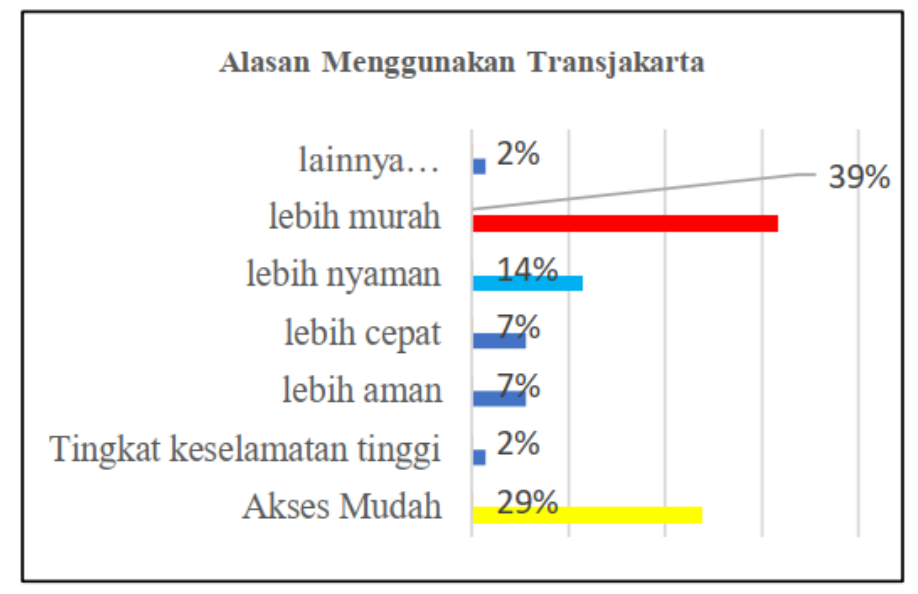

Figure 1. Reasons to use Transjakarta

However, Transjakarta also has several shortcomings, such as being late in arriving frequently. This is because private vehicle users who are stuck in traffic violate traffic rules by entering the busway lane which causes the speed of Transjakarta buses to be obstructed. In addition, the comfort factor is also a concern of the community because they often have to jostle with other people both when getting on the bus and while on the bus. This triggers crimes like harassment, pickpocketing, etc.

3. Elektric Rail Train (KRL)

This public transportation operates under PT Kereta Commuter Indonesia (KAI Commuter) which is a subsidiary of PT Kereta Api Indonesia (PT KAI). It started 
operating in 1925 until now, which crosses the areas of Jakarta, Bogor, Depok, Tangerang and Bekasi or commonly abbreviated as Jabodetabek. Currently, the number of KRL stations has reached 79 stations throughout Jabodetabek with route coverage reaching $418.5 \mathrm{~km}$ (11). It is calculated that in June 2018 the average number of KRL passengers per day reached 1,001,438 passengers on weekdays. The highest number of passengers served in one day reached 1,154,080.

Because this is rail-based public transportation, it will not be stuck in traffic jams (12). However, his arrival is often not on time or on time for the operation. This is because the number of passengers is not balanced with the number of carriages that are functioning or exceeding capacity. In addition, infrastructure maintenance is not carried out properly, such as rail lines that widen and cause trains to leave the railroad tracks.

4. Mass Rapid Transit (MRT)

The MRT project began construction on October 10, 2013 and began operating on March 24, 2019. With a route from Lebak Bulus to Bundaran HI (13). This transportation has a special route which is regulated in Article 1 paragraph (6) of the Provincial Regulation of the Special Capital Region of Jakarta Number 3 of 2008 concerning the Establishment of Regional Owned Enterprises (BUMD) Limited Liability Companies (PT) MRT Jakarta and also Article 1 paragraph (6) of the Regulation The Governor of DKI Jakarta Number 53 of 2017 concerning the Assignment of Limited Liability Companies to MRT Jakarta for the Implementation of Mass Rapid Transit Infrastructure and Facilities that: Mass Rapid Transit (MRT), is mass transportation based on rail roads that utilize special routes.

Currently the MRT's operational time is adjusted to the Large-Scale Social Restrictions (PSBB) policy due to the pandemic. On weekdays starting from 05.0021.00 with 10-5 minute intervals during peak hours (07.00-09.00 \& 17.00-19.00) while on weekends and holidays 06.00-20.00 hours are shortened from working days.

The MRT consists of 6 carriages and from a square perspective, it is a public transport with the largest capacity at 1,950 people. In terms of facilities and services provided are also comfortable. Can go at a speed of $80 \mathrm{~km} / \mathrm{h}$ in order to be on time. The MRT also provides facilities for persons with disabilities to continue using this public transportation (14). Overall it is good, but unfortunately it is not equipped with clear information to explain certain parts. In addition, because the general public uses 
the MRT, Poins Square, which the MRT passes through, has become a crowded place which eventually becomes a place of business (15).

5. Light Rail Transit (LRT)

Started to be built in 2015 in stages. In the first phase, a route was built from Bekasi Timur-Cawang-Kuningan-Dukuh Atas, and Cibubur Cawang (16). The construction in this first stage requires a cost of 2,745 T. It is planned that there are 6 operational corridors for the Jabodebek LRT which will be targeted for completion by the end of 2018, namely the depot station on Jalan Pegangsaan Dua Kelapa Gading, Mall Kelapa Gading station, Kelapa Gading Boulevard station, Pulomas station, Pacuan Kuda Station. up to Velodrome Station (17). Currently, the total LRT development presentation has reached $86.67 \%$ and is targeted to be completed in August or September 2021.

Some of the advantages and disadvantages of LRT are the system used, namely GOA 3 , which is the latest technology used as a city train driving system. GOA 3 has a movable block system that allows this train to be operated by a computer system in real time so that it does not require a driver on the train. And the LRT engine control room is completely centralized in the Operations Control Center or OCC (18). Because it uses a moving block system, the LRT is considered to be more effective in its operation so that the waiting time or headway will be faster, which is estimated to be less than 3 minutes. In addition, the ticket price is also cheaper than the MRT, around Rp. 12,000 for all routes, this price includes subsidies. Meanwhile, the commercial price is Rp. 25,000 and the government will provide a 50\% subsidy through public service obligations.

\section{DISCUSSION}

Because Jakarta is the capital city of Indonesia and has become a metropolitan city, the flow of urbanization is inevitable. As a result, population growth in Jakarta is very high and the need for transportation facilities has also increased. However, public transportation in Jakarta has not been able to meet these needs. Apart from that, the factors of convenience, safety, and flexibility in time from public transportation also make people reluctant to use them and prefer to use private vehicles. Thus, private vehicles are becoming increasingly dominant and the number continues to increase, both motorbikes and cars. So that this raises various problems, including increasing the use of fuel, air pollution pollution, and traffic jams.

Therefore, to overcome these problems the Provincial Government of DKI Jakarta has implemented various policies. The first is to increase the capacity of the road network or build 
new roads. Such as the Casablanca-Tanah Abang Non-Toll Road which was inaugurated by Governor Joko Widodo. Started to be used since December 30, 2013. This project is valued at IDR 737 billion. Built to withstand earthquakes on the 8-9 Richter scale. This non-toll flyover is 12 meters above the ground with a 2,700 meter lane which was built by PT Istaka Karya, PT Adhi Karya, and PT Wijaya Karya. In addition, the construction of a new road is also being carried out for the busway route, namely the Ciledug-Tendean Flyover which is used for Transjakarta bus corridor 13 on the Ciledug-Blok M route. Development was carried out from 2015 to 2016 with a budget of up to 2.5 trillion. This flyover will be built with a road length of 9.4 kilometers, with a height of 12 meters above the ground and a width of 20 meters (19).

Second, manipulating or regulating traffic, such as implementing an odd-even policy based on the number plates of each vehicle. This policy is only for 4-wheeled vehicles but does not apply to motorbikes, government apparatus cars, public transport cars, fire engines, official vehicles, and goods transport with special dispensations. The mechanism is a vehicle with a number plate behind an odd number on an odd date, and a phone number on an even date. Valid Monday to Friday, from 07.00 - 10.00 and 16.00 - 20.00. while for Saturdays, Sundays and national holidays this policy does not apply. This policy is also implemented in several roads, namely MH Thamrin, Jenderal Sudirman, and Gatot Subroto (20).

Third, the use of public transportation to reduce the number of private vehicles. This is done by updating, upgrading, and building public transportation facilities, especially rail-based public transportation, with the aim that people prefer to use public transportation rather than private vehicles in carrying out their activities. Thus, if this goal is achieved, the number of vehicles on the road will decrease so that congestion can be resolved. We can see this in the construction of the MRT and LRT.

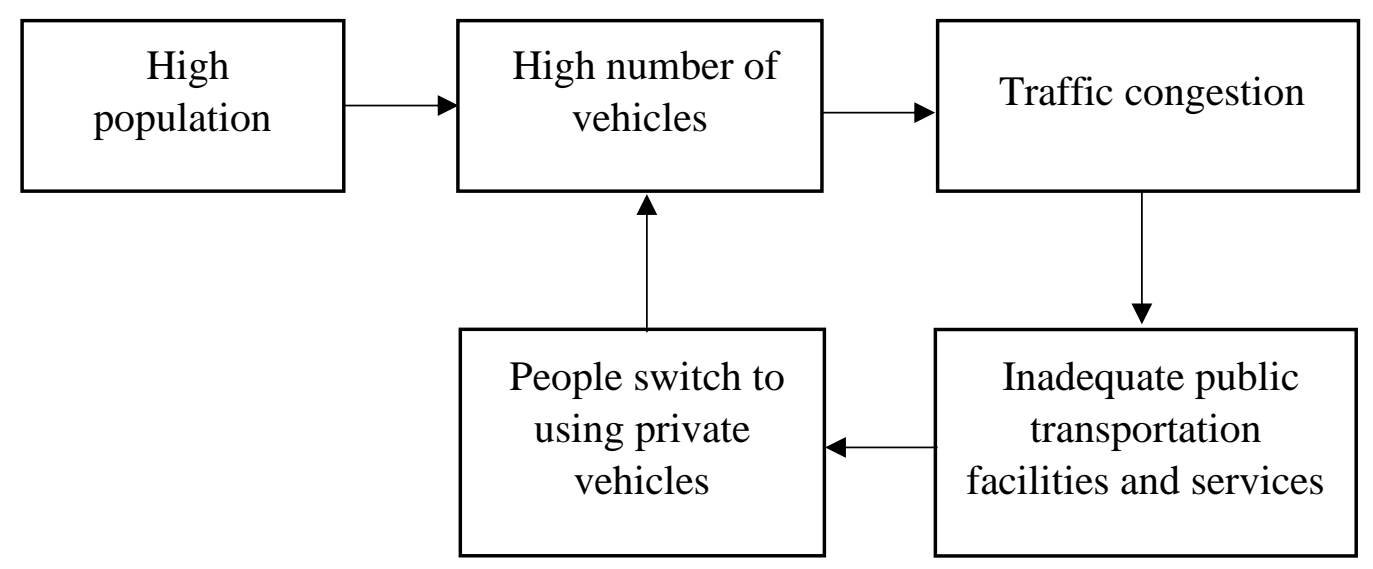


Basically, the cause of congestion that still occurs is the high population in Jakarta. This is because Jakarta is the capital city of Indonesia and has become a metropolitan city. So that the flow of urbanization of people from outside the region is very high. The high population also affects the need for transportation facilities that continue to increase, both public transportation and private vehicles. As a result, traffic jams continue to occur. In addition, the lack of public transportation facilities and services in Jakarta is also one of the causes of congestion. People do not trust public transportation as an effective and efficient means of transportation, so they prefer to use private vehicles.

\section{CONCLUSION}

In conclusion, even though these steps have been implemented, why does the congestion still occur? and what is the solution to solve it?. To answer this question, it is necessary to remember that people living in Jakarta do not only come from within the region but also come from outside the region. The high flow of urbanization is due to the fact that Jakarta is the capital city of Indonesia as well as the economic center of Indonesia. So that many people from rural areas work in Jakarta. This has contributed to an increase in the number of private vehicles that cause congestion. If only the native population of Jakarta, the existing means of transportation would meet the needs of the community in carrying out their activities and there would be no congestion. However, due to the large number of immigrants from outside the region and the economic conditions that cause the entry and exit of various modes of transportation, the existing means of transportation in Jakarta have not been able to do this.

The solution that can be done in addition to improving transportation facilities is the DKI Jakarta Provincial Government to coordinate with related parties who can help overcome these problems, such as the Transportation Agency, Social Service, and Statistics Agency from various regions. This is done in order to obtain data which is then analyzed further. In this case, the science of history can contribute to obtaining an effective and efficient means of transportation, besides that mistakes in decision making or policy implementation that have occurred in the past, especially in the field of transportation, will not be repeated.

Thus, the existing transportation facilities in Jakarta are quite effective and efficient to meet the needs of the community in carrying out their daily activities. However, it has not been able to meet the needs due to the flow of urbanization and high economic activity.

This research is only limited to land transportation facilities, while the types of water/sea transportation and air transportation are not included in the discussion. In addition, this research is also limited to the DKI Jakarta area. Altough, this article can be considered in 
the application of transportation facilities in other big cities in Indonesia. Especially cities that face congestion as the main problem of transportation facilities.

\section{REFERENCES}

1. Ruly R, Siska A, Viki A, Az Z. (C) Jurnal Pemikiran Pendidikan dan Penelitian Kesejarahan Perkembangan Transportasi Kereta Api di Jakarta. 2020;7(1):40-8.

2. Lahitani S. Ini Jadinya Kalau Trem Masih Ada di Jakarta. liputan6.com [Internet]. 2017; Available from: https://www.liputan6.com/citizen6/read/3187646/ini-jadinya-kalautrem-masih-ada-di-jakarta\#: :text=Sejarah trem di Batavia (kelak,merdeka\%2C jaringan trem pun diputus.

3. Munawar A. Perencanaan Angkutan Umum Perkotaan Berkelanjutan. Unisia. 2006;29(59):53-9.

4. Nasrulloh M. Sistem Bus Indonesia. 2010;1-8.

5. Fitria. Quo Vadis Transportasi Publik Di Ibukota: Sebuah Masalah, Tantangan Dan Solusi. J Chem Inf Model. 2013;53(9):1689-99.

6. Tamin O. Konsep Manajemen Kebutuhan Transportasi (MKT) Sebagai Alternatif Pemecah Masalah Transportasi Perkotaan di DKI Jakarta. Vol. 10, Journal of Regional and City Planning. 1999. p. 10-22.

7. Jakarta BP. Kepadatan Penduduk DKI Jakarta. statistik.jakarta.go.id [Internet]. 2020; Available from: https://statistik.jakarta.go.id/berapa-kepadatan-penduduk-dki-jakartasaat-ini/

8. Suryani F, Natadipura RK, ... Optimalisasi Rute Perjalanan Sarana Angkutan Umum Terpadu Bogor-Jakarta. Ikra-Ith Teknol ... [Internet]. 2019;3(2):63-75. Available from: http://journals.upi-yai.ac.id/index.php/ikraith-teknologi/article/view/708

9. Alam FS. Pengguna Jasa Angkutan Umum Jenis Angkot di Jakarta Dalam Perspektif Hukum Perlindungan Konsumen. SALAM J Sos dan Budaya Syar-i. 2016;3(2):197216.

10. Kurniati R. Dampak Ekonomi Pengoperasian Transjakarta Ditinjau dari Persepsi Pengguna. J Chem Inf Model [Internet]. 2020;53(9):1689-99. Available from: http://ppid.dephub.go.id/files/datalitbang/Jurnal_Darat_2015.pdf

11. Tambunan E. Analisis Kualitas Pelayanan Ka Commuter Line Rute ParungpanjangTanah Abang. 2020;1(1):15-23.

12. Wijayanto H. Peranan Penggunaan Transportasi Publik di Perkotaan (Studi Kasus Penggunaan Kereta Commuterline Indonesia Rute Jakarta-Bekasi). Kybernan J Stud Kepemerintahan. 2019;5(2):1-8.

13. Yuniarti A, Aditya T. Service Quality Terhadap Kepuasan Masyarakat Mass Rapid Transit (Mrt) DKI Jakarta di Stasiun Lebak Bulus Pada Masa Pandemik Covid-19. J Ilm Ilmu Adm. 2020;10(2):55-69.

14. K ALAW, Syarief A, Rudyanto G. Kajian Aksesibilitas Untuk Penyandang Disabilitas Pada Stasiun Mrt Jakarta. J Seni dan Reka Ranc. 2020;2(2):207-30.

15. Fatmawati, Lubis. Jurnal Muhammadiyah Manajemen Bisnis. Pengaruh Perilaku Kewirausahaan Terhadap Kemamp Manajerial Pada Pedagang Pakaian Pasar Pus Pasar Kota Medan. 2020;1(1):57-66.

16. Sianipar A. Kajian Preferensi Masyarakat Dalam Menggunakan Lrt Jabodebek. J Penelit Transp Darat. 2020;21(1):13-20.

17. Kristiana R, Studi P, Sipil T, Buana UM. Analisis Pengukuran Kualitas Kinerja Infrastruktur. 2020;X(1):85-94. 
18. Magazine SO. Berikut Ini Beberapa Keunggulan LRT Jabodebek Dibanding MRT Jakarta. $\quad$ swa.co.id [Internet]. 2019; Available from: https://swa.co.id/swa/trends/technology/berikut-ini-beberapa-keunggulan-lrtjabodebek-di-banding-mrt-jakarta

19. Philip FJ, Fassa F. Analisis Efektifitas Kinerja Layanan Jalan Layang Non Tol Studi Kasus Tanah Abang - Kampung Melayu. Widyakala J. 2015;2(1):105.

20. JSC. Penerapan Kebijakan Ganjil-Genap di Jakarta. https://smartcity.jakarta.go.id/ [Internet]. 2015; Available from: https://smartcity.jakarta.go.id/blog/84/penerapankebijakan-ganjil-gena

21. Sugiyono. Metode Penelitian Pendidikan (Pendekatan Kuantitatif, Kualitatif, dan R\&D). Bandung: Penerbit Alfabeta. 2015.

22. Zed M. Metode Penelitian Kepustakaan. Jakarta: Yayasan Obor Indonesia. 2008.

23. Sidiq U, Choiri M. Metode Penelitian Kualitatif di Bidang Pendidikan. Ponorogo: CV Nata Karya. 2019.

Table 1. List of Journal Articles and their Findings

\begin{tabular}{|c|c|c|c|}
\hline Author & Method & $\begin{array}{l}\text { Title and Year of } \\
\text { Publication }\end{array}$ & Result \\
\hline $\begin{array}{l}\text { Jumardi, Ruly, } \\
\text { Abdulhaadi, } \\
\text { Atika, Viki, } \\
\text { Zaki }\end{array}$ & $\begin{array}{l}\text { Historical } \\
\text { and } \\
\text { Interview }\end{array}$ & $\begin{array}{l}\text { Perkembangan } \\
\text { Transportasi } \\
\text { Kereta Api Di } \\
\text { Jakarta (2020) }\end{array}$ & $\begin{array}{l}\text { The history of land public transportation in } \\
\text { Jakarta has been started since the colonial era. }\end{array}$ \\
\hline $\begin{array}{l}\text { Ahmad } \\
\text { Munawar }\end{array}$ & - & $\begin{array}{l}\text { Perencanaan } \\
\text { Angkutan Umum } \\
\text { Perkotaan } \\
\text { Berkelanjutan } \\
(2006)\end{array}$ & $\begin{array}{l}\text { The problem is how to meet the demand for } \\
\text { the number of trips that are increasing but not } \\
\text { causing congestion. }\end{array}$ \\
\hline M. Nasrulloh & - & $\begin{array}{l}\text { Sistem Bus } \\
\text { Indonesia (2010) }\end{array}$ & $\begin{array}{l}\text { Population growth and increased community } \\
\text { mobility are one of the factors that cause } \\
\text { these problems. }\end{array}$ \\
\hline Fitria & - & $\begin{array}{l}\text { Quo Vadis } \\
\text { Transportasi } \\
\text { Publik Di Ibukota : } \\
\text { Sebuah Masalah, } \\
\text { Tantangan Dan } \\
\text { Solusi (2017) }\end{array}$ & $\begin{array}{l}\text { Public transportation has various } \\
\text { shortcomings both in terms of services and } \\
\text { facilities. } \\
\text { People are reluctant to use public } \\
\text { transportation and prefer to use private } \\
\text { vehicles because they are considered more } \\
\text { comfortable, safe, and flexible in their use. } \\
\text { The uncontrolled increase in the number of } \\
\text { private vehicles causes various problems such } \\
\text { as increased fuel use, air pollution, and traffic } \\
\text { jams. }\end{array}$ \\
\hline $\begin{array}{l}\text { Faris Satria } \\
\text { Alam }\end{array}$ & - & $\begin{array}{l}\text { Penggunaan Jasa } \\
\text { Angkutan Umum } \\
\text { Jenis Angkot Di } \\
\text { Jakarta Dalam ktif } \\
\text { Hukum }\end{array}$ & $\begin{array}{l}\text { Angkot has been operating since } 1943 \text { when } \\
\text { Indonesia was still colonized by Japan. } \\
\text { In 1946, public transportation became part of } \\
\text { DAMRI (Djawatan Angkoetan Motor } \\
\text { Repoeblik Indonesia) as public transportation. }\end{array}$ \\
\hline
\end{tabular}




\begin{tabular}{|c|c|c|c|}
\hline & & $\begin{array}{l}\text { Perlindungan } \\
\text { Konsumen (2016) }\end{array}$ & \\
\hline Kurniati R & $\begin{array}{l}\text { Observati } \\
\text { on, } \\
\text { Interview } \\
\text { Documen } \\
\text { tation, } \\
\text { Question } \\
\text { naire }\end{array}$ & $\begin{array}{l}\text { Dampak Ekonomi } \\
\text { Pengoperasian } \\
\text { Transjakarta } \\
\text { Ditinjau dari } \\
\text { Persepsi Pengguna } \\
\text { (2020) }\end{array}$ & $\begin{array}{l}\text { Transjakarta is a public transportation owned } \\
\text { by DKI Jakarta Regional Owned Enterprises } \\
\text { (BUMD). } \\
\text { Started operating in } 2004 \text { until now with a } \\
\text { fleet of more than } 2,000 \text { buses and } 200 \text { travel } \\
\text { routes. } \\
\text { Details of the reasons why people use } \\
\text { Transjakarta } 39 \% \text { answered that it was } \\
\text { cheaper, } 29 \% \text { answered that it was easy to } \\
\text { access, } 14 \% \text { was more comfortable, } 7 \% \text { was } \\
\text { faster and safer, and } 2 \% \text { had a higher level of } \\
\text { security than other transportation. And for } \\
\text { details in the operation of the Transjakarta } \\
\text { bus, the return trip frequency is } 89 \% \text {, the } \\
\text { maximum travel time is one to two hours by } \\
57 \% \text { and the waiting time at the bus stop is } \pm \\
10-15 \text { minutes by } 42 \% \text {. }\end{array}$ \\
\hline E. Tambunan & $\begin{array}{l}\text { Field } \\
\text { Research }\end{array}$ & $\begin{array}{l}\text { Analisis Kualitas } \\
\text { Pelayanan Ka } \\
\text { Commuter Line } \\
\text { Rute } \\
\text { Parungpanjang- } \\
\text { Tanah Abang } \\
(2020)\end{array}$ & $\begin{array}{l}\text { KRL operates under PT Kereta Commuter } \\
\text { Indonesia (KAI Commuter) which is a } \\
\text { subsidiary of PT Kereta Api Indonesia (PT } \\
\text { KAI). } \\
\text { Started operating in } 1925 \text { until now, across } \\
\text { the Greater Jakarta area. } \\
\text { The number of KRL stations is } 79 \text { stations } \\
\text { throughout Jabodetabek with a route coverage } \\
\text { of } 418.5 \mathrm{~km} \text {. }\end{array}$ \\
\hline H. Wijayanto & $\begin{array}{l}\text { Impleme } \\
\text { ntation } \\
\text { and Case } \\
\text { Studies }\end{array}$ & $\begin{array}{l}\text { Peranan } \\
\text { Penggunaan } \\
\text { Transportasi } \\
\text { Publik di } \\
\text { Perkotaan (Studi } \\
\text { Kasus Penggunaan } \\
\text { Kereta } \\
\text { Commuterline } \\
\text { Indonesia Rute } \\
\text { Jakarta-Bekasi) } \\
\text { (2019) }\end{array}$ & $\begin{array}{l}\text { Rail-based public transportation, won't get } \\
\text { stuck in traffic.. }\end{array}$ \\
\hline $\begin{array}{l}\text { A. Yuniarti, } \\
\text { T. Aditya }\end{array}$ & $\begin{array}{l}\text { Quantitati } \\
\text { ve }\end{array}$ & $\begin{array}{l}\text { Service Quality } \\
\text { Terhadap } \\
\text { Kepuasan } \\
\text { Masyarakat Mass } \\
\text { Rapid Transit } \\
\text { (MRT) Dki Jakarta } \\
\text { Di Stasiun Lebak } \\
\text { Bulus Pada Masa } \\
\text { Pandemik Covid- } \\
19(2020)\end{array}$ & $\begin{array}{l}\text { The MRT project began construction on } \\
\text { October 10, } 2013 \text { and began operating on } \\
\text { March 24, 2019. With a route from Lebak } \\
\text { Bulus to Bundaran HI. }\end{array}$ \\
\hline
\end{tabular}




\begin{tabular}{|c|c|c|c|}
\hline $\begin{array}{l}\text { A. K, A. } \\
\text { Syarief, } \\
\text { G. Rudyanto }\end{array}$ & $\begin{array}{l}\text { Universal } \\
\text { Design } \\
\text { on Mass } \\
\text { Transport } \\
\text { ation }\end{array}$ & $\begin{array}{l}\text { Kajian } \\
\text { Aksesibilitas } \\
\text { Untuk Penyandang } \\
\text { Disabilitas Pada } \\
\text { Stasiun Mrt } \\
\text { Jakarta (2020) }\end{array}$ & $\begin{array}{l}\text { The MRT consists of } 6 \text { carriages.It is a rail- } \\
\text { based public transportation with the largest } \\
\text { capacity of } 1,950 \text { people. Can go at a speed of } \\
80 \mathrm{~km} / \mathrm{h} \text {. MRT also provides facilities for } \\
\text { people with disabilities to continue using this } \\
\text { public transportation transportasi. }\end{array}$ \\
\hline $\begin{array}{l}\text { Fajar Adi } \\
\text { Prakoso, } \\
\text { Sampor Ali }\end{array}$ & $\begin{array}{l}\text { Field } \\
\text { Research }\end{array}$ & $\begin{array}{l}\text { Analisis Dampak } \\
\text { Pengoperasian } \\
\text { Mass Rapid } \\
\text { Transit (MRT) } \\
\text { Terhadap } \\
\text { Penjualan Produk } \\
\text { dan Keputusan } \\
\text { Pembelian } \\
\text { Konsumen (2020) } \\
\end{array}$ & $\begin{array}{l}\text { Poins Square, which is passed by the MRT, } \\
\text { has become a busy place which eventually } \\
\text { became a place of business. }\end{array}$ \\
\hline A. Sinapiar & $\begin{array}{l}\text { Descripti } \\
\text { ve } \\
\text { Analysis }\end{array}$ & $\begin{array}{l}\text { Kajian Preferensi } \\
\text { Masyarakat Dalam } \\
\text { Menggunakan } \\
\text { LRT Jabodebek } \\
\text { (2019) }\end{array}$ & $\begin{array}{l}\text { The LRT began to be built in } 2015 \text { in stages. } \\
\text { In the first stage, the route will be built from } \\
\text { Bekasi Timur-Cawang-Kuningan-Dukuh } \\
\text { Atas, and Cibubur Cawang. }\end{array}$ \\
\hline $\begin{array}{l}\text { R. Kritiana, S. } \\
\text { Jodi }\end{array}$ & $\begin{array}{l}\text { Field } \\
\text { Research }\end{array}$ & $\begin{array}{l}\text { Analisis } \\
\text { Pengukuran } \\
\text { Kualitas Kinerja } \\
\text { Infrastruktur Lrt } \\
\text { Jakarta Selama } \\
\text { Kondisi Pandemi } \\
\text { Covid-19 (2020) }\end{array}$ & $\begin{array}{l}\text { The construction of the first phase cost } 2.745 \\
\text { trillion. There are } 6 \text { Jabodebek LRT } \\
\text { operational corridors targeted for completion } \\
\text { by the end of } 2018 \text {, namely depot stations on } \\
\text { Jalan Pegangsaan Dua Kelapa Gading, Mall } \\
\text { Kelapa Gading Station, Kelapa Gading } \\
\text { Boulevard Station, Pulomas Station, and } \\
\text { Horse Racing Station go to Velodrome } \\
\text { Station. }\end{array}$ \\
\hline $\begin{array}{l}\text { S. Fitri, K. } \\
\text { Natadipura, T. } \\
\text { Halimah }\end{array}$ & - & $\begin{array}{l}\text { Optimalisasi Rute } \\
\text { Perjalanan Sarana } \\
\text { Angkutan Umum } \\
\text { Terpadu Bogor- } \\
\text { Jakarta (2019) } \\
\end{array}$ & $\begin{array}{l}\text { Determination of erratic public transportation } \\
\text { fares, limited numbers, feasibility of public } \\
\text { transportation vehicles related to comfort, and } \\
\text { passenger safety from crimes such as } \\
\text { pickpockets or others. }\end{array}$ \\
\hline Ofyar Z Tamin & - & $\begin{array}{l}\text { Konsep } \\
\text { Manajemen } \\
\text { Kebutuhan } \\
\text { Transportasi } \\
\text { (MKT) Sebagai } \\
\text { Alternatif } \\
\text { Pemecahan } \\
\text { Masalah } \\
\text { Transportasi } \\
\text { Perkotaan Di DKI } \\
\text { Jakarta (1999) }\end{array}$ & $\begin{array}{l}\text { Currently, Indonesia is a country that is in the } \\
\text { development stage. }\end{array}$ \\
\hline $\begin{array}{l}\text { F. Philip, F. } \\
\text { Fassa }\end{array}$ & - & $\begin{array}{l}\text { Analisis } \\
\text { Efektivitas Kinerja } \\
\text { Layanan Jalan } \\
\text { Layang Non Tol, } \\
\text { Studi Kasus Tanah }\end{array}$ & $\begin{array}{l}\text { The construction of the Casablanca-Tanah } \\
\text { Abang Non-Toll Road which was inaugurated } \\
\text { by Governor Joko Widodo. It has been in use } \\
\text { since December } 30,2013 \text {. This project is } \\
\text { valued at Rp. } 737 \text { billion. Built to withstand }\end{array}$ \\
\hline
\end{tabular}




\begin{tabular}{|l|l|l|}
\hline \multirow{5}{*}{} & $\begin{array}{l}\text { Abang-Kampung } \\
\text { Melayu (2015) }\end{array}$ & $\begin{array}{l}\text { earthquakes on the 8-9 Richter scale. This } \\
\text { non-toll road flyover is 12 meters above } \\
\text { ground level with a track length of 2,700 } \\
\text { meters which was built by PT Istaka Karya, } \\
\text { PT Adhi Karya, and PT Wijaya Karya. }\end{array}$ \\
& $\begin{array}{l}\text { The construction of the Ciledug-Tendean } \\
\text { Flyover busway, which is used for } \\
\text { Transjakarta buses, corridor 13, lane M, } \\
\text { Ciledug-Blok. The construction was carried } \\
\text { out from 2015 to 2016 with a budget of up to } \\
2.5 \text { trillion. This flyover will be built with a } \\
\text { road length of 9.4 kilometers, with a height of } \\
12 \text { meters above ground level and a width of } \\
20 \text { meters. }\end{array}$ \\
\hline
\end{tabular}

